\title{
Different corrosive effects on hydroxyapatite nanocrystals and amine fluoride-based mouthwashes on dental titanium brackets: a comparative in vitro study
}

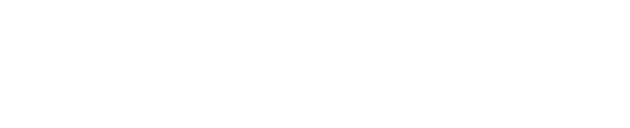

\author{
Marco Lelli' \\ Olivia Marchisio ${ }^{2}$ \\ Ismaela Foltran' \\ Annamaria Genovesi ${ }^{2}$ \\ Giulia Montebugnoli' \\ Massimo Marcaccio' \\ Ugo Covani ${ }^{2}$ \\ Norberto Roveri \\ 'Alma Mater Studiorum, University of \\ Bologna, Department of Chemistry, \\ Bologna, Italy; ${ }^{2}$ University of Pisa, \\ Istituto Stomatologico Tirreno, Lido \\ di Camaiore, Lucca, Italy
}

\begin{abstract}
Titanium plates treated in vitro with a mouthwash containing amine fluoride (100 ppm $\mathrm{F}^{-}$) and another containing zinc-substituted carbonate-hydroxyapatite have been analyzed by scanning electron microscopy and atomic force microscopy to evaluate the modification of the surface roughness induced by treatment with these two different mouthwashes. The treatment with $\mathrm{F}^{-}$-based mouthwash produces a roughness characterized by higher peaks and deeper valleys in the streaks on the titanium bracket surface compared with those observed in the reference polished titanium plates. This effect causes a mechanical weakness in the metallic dental implant causing bacterial growth and therefore promotes infection and prosthesis contamination. However, the in vitro treatment with a mouthwash containing zincsubstituted carbonate-hydroxyapatite reduced the surface roughness by filling the streaks with an apatitic phase. This treatment counteracts the surface oxidative process that can affect the mechanical behavior of the titanium dental implant, which inhibits the bacterial growth contaminating prostheses.
\end{abstract}

Keywords: mouthwash, titanium brackets, corrosion, hydroxyapatite, aminic fluoride

\section{Introduction}

The use of titanium in dental implant materials is based on the low thermal conductivity of this metal, besides the fact that it doesn't release toxic ions and has an appropriate elasticity module, which helps bone to heal when in close contact with the titanium implant surface. ${ }^{1}$

Titanium is highly ductile and resistant to cyclic forces in the oral environment. These cyclic forces, known as fatigue, are produced by masticatory movements, which are capable of causing internal microcracks in titanium-based implants. ${ }^{2}$ Titanium constantly undergoes mechanical and thermal stresses in an aggressive host oral environment.

Mouthwashes and toothpastes containing fluoride ions are among the most important products in the oral care market. In fact, fluoride has been considered the main method to reduce the enamel dissolution and prevent caries. Fluoride ions have the ability to interact with the hydroxyapatite crystals forming fluoridated hydroxyapatite $\left(\mathrm{Ca}_{10}\left(\mathrm{PO}_{4}\right)_{6}(\mathrm{OH}) \mathrm{F}\right)$ or fluorapatite $\left(\mathrm{Ca}_{10}\left(\mathrm{PO}_{4}\right)_{6} \mathrm{~F}_{2}\right)$. These minerals have greater lattice energy, higher crystallinity, and better resistance to dissolution than hydroxyapatite. Fluoride also increases the seeding rate of apatite crystals. ${ }^{1}$
Correspondence: Norberto Roveri Department of Chemistry "G Ciamician", Alma Mater Studiorum University of Bologna,Via Selmi 2, I-40I 26 Bologna, Italy Tel +3905 I209 9486

Fax +3905 I2099593

Email norberto.roveri@unibo.it 
The in vivo treatment using fluoride toothpastes may lead to a partial substitution of the hydroxylic groups with fluoride ions in the native enamel hydroxyapatite..$^{3,4}$

The bone-promoting activity of $\mathrm{F}^{-}$has been extensively documented in the literature. ${ }^{16}$ Titanium fluoride forms a stable layer on hydroxyapatite surfaces where titanium shares the oxygen atoms of phosphate, which becomes covalently bound to the hydroxyapatite surface. Fluoride is essential in this reaction because it allows phosphate ions to react directly with titanium to form a firm and stable connection. ${ }^{1}$ The oxygen and phosphate in the tissue fluids may replace the fluoride and the phosphate becomes covalently bound to the titanium surface. Such a reaction may induce a bone formation where the phosphate in the bone is firmly (covalently) bound to the titanium implant. This process may catalyze bone formation and facilitate deposition of particularly well-mineralized bone tissue close to the implant surface. 5,6

Oxidative processes can thicken and condense the titanium oxide layer on the surface, which improves the anticorrosion stability of the underlying titanium. ${ }^{7,8}$ On the other hand, reductive agents, such as fluoride $\left(\mathrm{F}^{-}\right)$, may have the opposite effect and attack this layer. ${ }^{8}$ The corrosion process is caused by electrochemical reactions. Titanium is known to present high resistance to corrosion against attack by solutions containing strong mineral acids, such as hydrochloric acid or sulfuric acid. However, when titanium is placed in contact with a fluorinated medium at $\mathrm{pH}$ below 3.5 , its titanium oxide layer is damaged and degraded. This phenomenon is macroscopically visible by the loss of surface brightness. ${ }^{9}{ }^{910}$ The fluorides may also cause corrosion, which increases roughness on the surfaces exposed to the oral cavity, making it easier for microorganisms to grow where they are protected from oral hygiene mechanisms (brushing, swallowing, and flow of crevicular fluid). ${ }^{2,11,12}$

Anodic polarization and immersion tests indicated that the titanium corrosion in solutions containing $\mathrm{F}^{-}$depends on the concentration of hydrofluoric acid (HF). The passivation film on titanium was destroyed when the HF concentration in the solution was $>30 \mathrm{ppm}$.

A rough surface favors plaque accumulation ${ }^{13}$ in the periimplant crevices of the gingiva, which is an undesirable effect in this very sensitive region of the implant. Accordingly, to avoid pathogenic plaque accumulation, ${ }^{14}$ the neck (abutment) of an implant must be polished. It is very important to ensure that these surfaces receive continuous care.

Many studies shown the high risk for fluoride to produce fluorosis, especially in children, and bone diseases in the elderly. ${ }^{15-21}$ The European Food Safety Authority (EFSA) scientific panel has advised that there is a risk of fluoride intake from ingested oral care products and toothpastes that can be fluoridated with a maximum level of $1500 \mathrm{mg} / \mathrm{Kg}$. The EFSA considers that the maximum fluoride intake should be $0.1 \mathrm{mg}$ fluoride $/ \mathrm{kg} /$ day in children aged $1-8$ years which is equivalent to 1.5 and $2.5 \mathrm{mg}$ fluoride per day in children aged 1-3 years and 4-8 years, respectively. ${ }^{22,23}$

Innovative commercial mouthwashes and toothpastes in the last decade have replaced fluoride with biomimetic hydroxyapatite nanocrystals as a remineralizing agent to avoid the dangerous effects of fluoride in human health, which have been ascribed to the amount of fluoride ingested daily. ${ }^{16}$

In the inorganic phase of bone and dental hard tissues, hydroxyapatite $\left[\mathrm{Ca}_{10}\left(\mathrm{PO}_{4}\right)_{6}(\mathrm{OH})_{2}\right](\mathrm{HA})$ has been widely studied as a bone filler, prosthetic coating, and implantable biomaterial in dentistry and orthopedic surgery because of its biocompatibility, bioactivity, and osteoconductivity. ${ }^{17}$

Biological HA is not stoichiometric according to the ideal formula $\mathrm{Ca}_{10}\left(\mathrm{PO}_{4}\right)_{6}(\mathrm{OH})_{2}$, but at low quantities $\mathrm{Ca}^{2+}$ is replaced by other ions such as $\mathrm{Na}^{+}, \mathrm{K}^{+}, \mathrm{Zn}^{2+}, \mathrm{Mg}^{2+}, \mathrm{Sr}^{2+}$, while $\mathrm{PO}_{4}^{3-}$ and $\mathrm{OH}^{-}$can be partially substituted by other anions like $\mathrm{CO}_{3}{ }^{2-}, \mathrm{HPO}_{4}{ }^{2-}, \mathrm{P}_{2} \mathrm{O}_{7}{ }^{4-}, \mathrm{SiO}_{4}{ }^{4-} \cdot{ }^{17,24-26}$

Carbonate is the prevalent foreign anion present into bonehydroxyapatite structure and represents about 4-8 wt \% ${ }^{27,28}$ The substitution of $\mathrm{CO}_{3}{ }^{2-}$ groups into the $\mathrm{PO}_{4}{ }^{3-}$ sites (type $\mathrm{B}$ carbonate apatite) is prevalent in children, while the carbonate replacement to $\mathrm{OH}^{-}$groups (type A carbonate apatite) increases with the age of the individual. ${ }^{29}$

Biomimetic carbonate-hydroxyapatite nanocrystals (CHA) have been synthesized nearly stoichiometrically in bulk $\mathrm{Ca} / \mathrm{P}$ molar ratio of about 1.7 and contains $4 \pm 1 \mathrm{wt} \%$ of carbonate ions that replaced prevalently phosphate groups. Biomimetic CHA nanocrystals have been synthesized from $20 \mathrm{~nm}$ to $100 \mathrm{~nm}$ (Figure 1) with both acicular and plate-like morphology to deliver drugs ${ }^{30-33}$ with a surface infused with amino acids and proteins..$^{26,34-36}$

Biomimetic CHA (Figure 2) can aggregate in microsized crystal clusters that have a nanostructured surface area of about $80 \mathrm{~m}^{2} / \mathrm{g}$ and can be utilized as mineralized agents in toothpastes and mouthwashes. ${ }^{37}$

Only recently, a chemical-physical experimental approach has been followed to investigate in vitro ${ }^{37,38}$ and in vivo ${ }^{3,4}$ the capability of CHA nanostructured crystals to produce in vivo biomimetic mineral deposition on enamel and dentin surfaces through daily use. ${ }^{11}$

Demineralized enamel and dentine slabs have been treated in vitro with synthetic biomimetic hydroxyapatite 


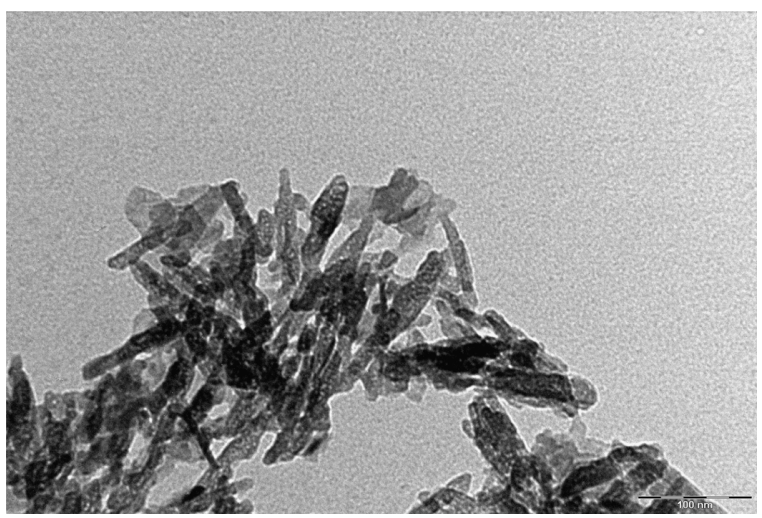

Figure I TEM image of biomimetic CHA nanocrystals.

Abbreviations: CHA, carbonate-hydroxyapatite; TEM, transmission electron microscopy.

nanocrystals for a few minutes and the surfaces chemically and physically characterized. CHA induces surface remineralization, which forms a biomimetic apatite coating on enamel and dentin surfaces. Enamel remineralization occurs quickly due to the specific chemical-physical characteristics of innovative nanostructured hydroxyapatite particles, which closely resemble the natural hydroxyapatite present in enamel ${ }^{39}$ Therefore, our experimental results suggest that the deterioration of teeth can be prevented.

CHA synthesized with tailored biomimetic characteristics for composition, structure, size, and morphology can chemically bind themselves on the surfaces of hard tissues in teeth, filling in the scratches, and producing a bound biomimetic apatitic coating to protect the enamel surface structure. ${ }^{3,40,41}$

There are some commercial products for oral care, like toothpastes and mouthwashes, based on CHA, which come into contact with titanium prostheses.

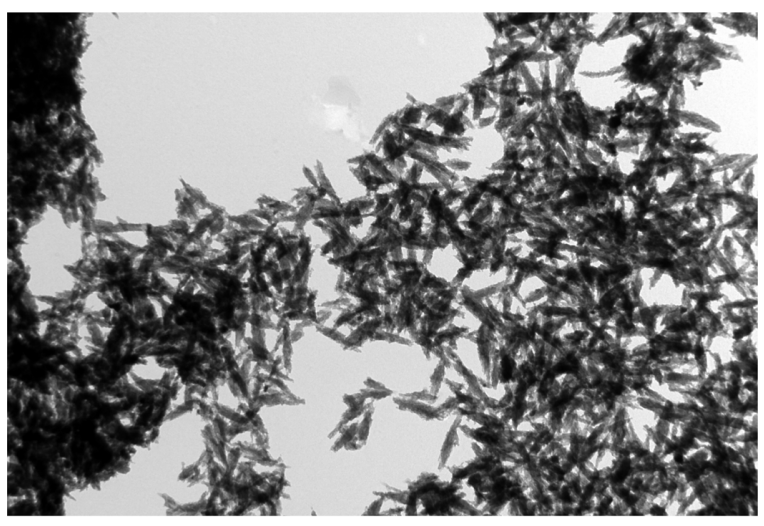

Figure 2 TEM image of aggregated biomimetic CHA nanocrystals.

Abbreviations: CHA, carbonate-hydroxyapatite; TEM, transmission electron microscopy.
The aim of this work is to evaluate the action of a nanostructured CHA-based mouthwash on titanium implants, in comparison with a $\mathrm{F}^{-}$-based mouthwash.

In this work, we have performed an in vitro analysis on the effect of $\mathrm{F}^{-}$and $\mathrm{CHA}$ on the surface of titanium brackets, using scanning electron microscopy (SEM) and atomic force microscopy (AFM), which allows a direct quantitative characterization of the surface roughness.

\section{Materials and method In vitro test}

We considered four types of titanium resulting from different processes: polished, blasted, machined, and acidetched. All samples were titanium grade plates $3 \mathrm{~mm}$ thick and $6 \mathrm{~mm}$ diameter. In vitro tests were carried out using six samples for each type of titanium. Polished titanium brackets were tested at room temperature in nanostructured microcrystal CHA-based mouthwash for comparison to an amine fluoride $\mathrm{F}^{-}$-based mouthwash with a $\mathrm{pH}$ ranging between 4.3 and 5.5. The stoichiometric composition of biomimetic CHA, which represents the active component in the used mouthwash, is $\mathrm{Ca}_{(10-\mathrm{x})} \mathrm{Zn}_{\mathrm{x}}\left(\mathrm{PO}_{4}\right)_{(6-\mathrm{y})}\left(\mathrm{CO}_{3}\right)_{\mathrm{y}}(\mathrm{OH})_{2}$ where $\mathrm{x}$ is 0.1 and $\mathrm{y}$ is 0.4 .

Each plate sample was dipped in mouthwash for 60 seconds, twice a day for 30 days to simulate a proper oral hygiene rinse. After each treatment, the titanium plates were washed under running water to replicate in vivo the usual teeth rinse procedure.

\section{Morphological characterization}

SEM observations were carried out by means of a CarlZeiss EVO, 40 XVP (Oberkochen, Germany) equipped with an energy dispersive detector (EDAX) Inca 250 (Oxford, UL), using secondary electrons at $25 \mathrm{KV}$ and different magnifications.

AFM was carried out directly on the titanium plate samples' substrates. AFM imaging was performed on a Digital Instruments Nanoscope IIIa Multimode SPM (Digital Instruments, Santa Barbara, CA, USA). The advanced analog and digital circuit designs and innovative software and hardware provide superior multitasking control for scanning probe microscopes (SPMs). ${ }^{42,43}$ The samples in contact mode using a $\mathrm{J}$ scanner and silicon nitride tips (200 lm long with nominal spring constant $0.06 \mathrm{~N} / \mathrm{m}$ ).

\section{Results}

The surface morphologies of different polished, blasted, machined, and acid-etched titanium plates have been charac- 


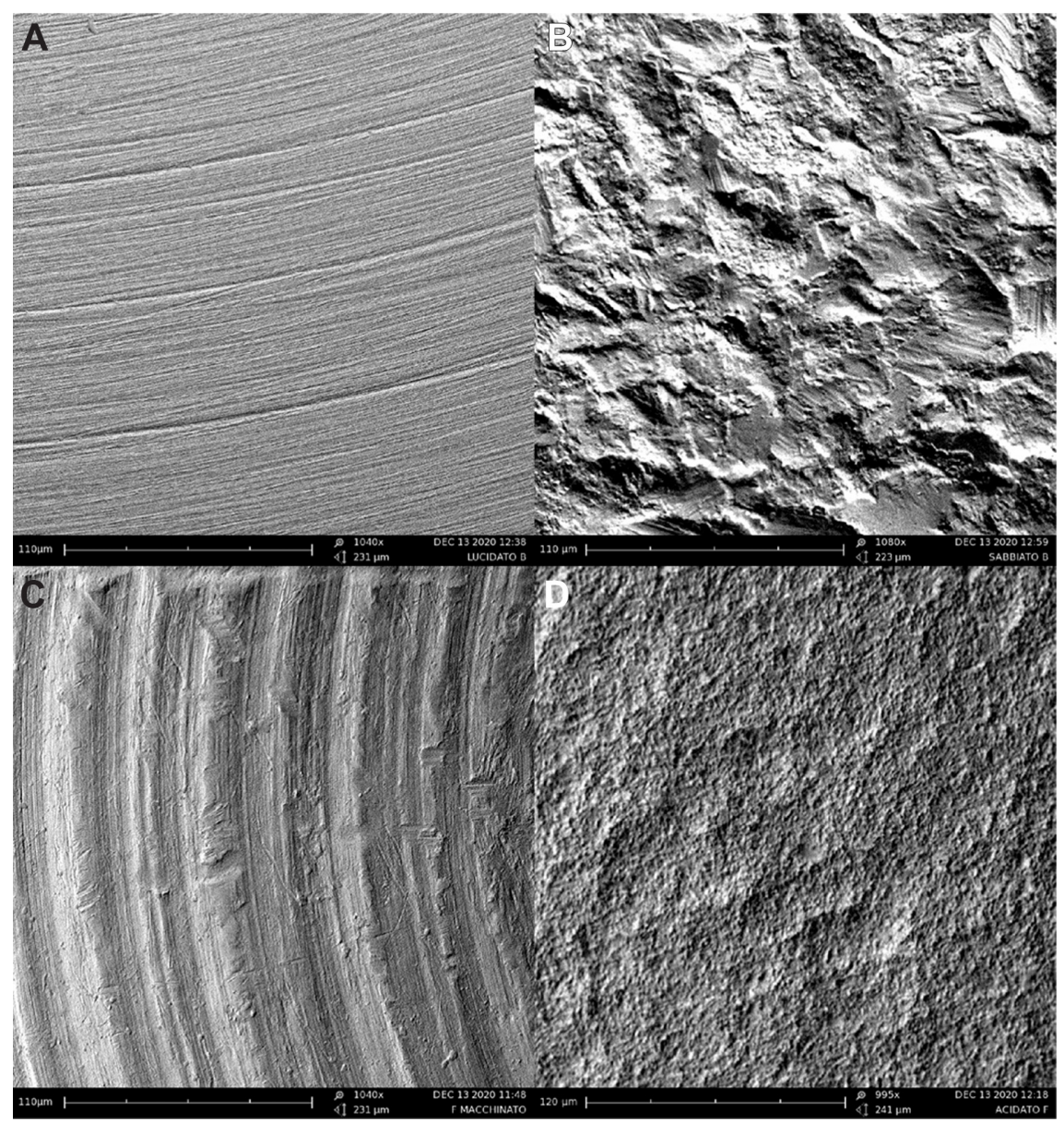

Figure 3 SEM images of the different polished, blasted, machined, and acid-etched titanium disk surfaces used in preliminary selection: (A) polished titanium surface, (B) blasted titanium surface, (C) machine-treated titanium surface, and (D) etched titanium surface.

Abbreviation: SEM, scanning electron microscopy.

terized by SEM and the images are reported in Figure 3A-D respectively.

Figure 3 shows that blasted, machine-treated, and acidetched titanium plates have an inhomogeneous surface, while the polished plate surface (Figure 3A) has low grooves and thus a smooth surface (Figure 3C). Polished titanium plates that have a homogeneous surface with a very small roughness appear to be the more suitable titanium plates to be utilized in this study.

Comparable samples of polished titanium plates have been surface characterized by SEM before and after a daily in vitro treatment with two different mouthwashes. A mouthwash containing an amine fluoride $\left(100 \mathrm{ppm} \mathrm{F}^{-}\right)$and another containing zinc-substituted CHA have been utilized to investigate their different effects on the titanium plate surface.

After the in vitro treatment with the two different mouthwashes, SEM analysis of the titanium plates showed an appreciable difference between the plates treated with amine $\mathrm{F}^{-}$-based mouthwash (Figure 4A) and those treated with the CHA-based mouthwash (Figure 4C). In fact, the surface roughness present on titanium surface increases after the treatment with amine $\mathrm{F}^{-}$-based mouthwash compared to that observed on the reference titanium plate (Figure 3A).

Contrarily, the CHA-based mouthwash seems to cover valleys and grooves present on the titanium surface, which appreciably reduces the roughness present on the reference titanium plates.

The EDAX elemental analysis performed on the surface of the titanium after treatment with a fluoride rinse showed only one peak related to titanium (Figure 4B). If the EDAX was performed after treatment with CHA-based mouthwash, the same survey grade showed peaks attributable to the calcium and phosphate ions present in the right stoichiometric molar ratio of hydroxyapatite, 1.7 (Figure 4D).

For more detailed results, the titanium brackets treated with the two different mouthwashes were investigated by AFM microscopy. 


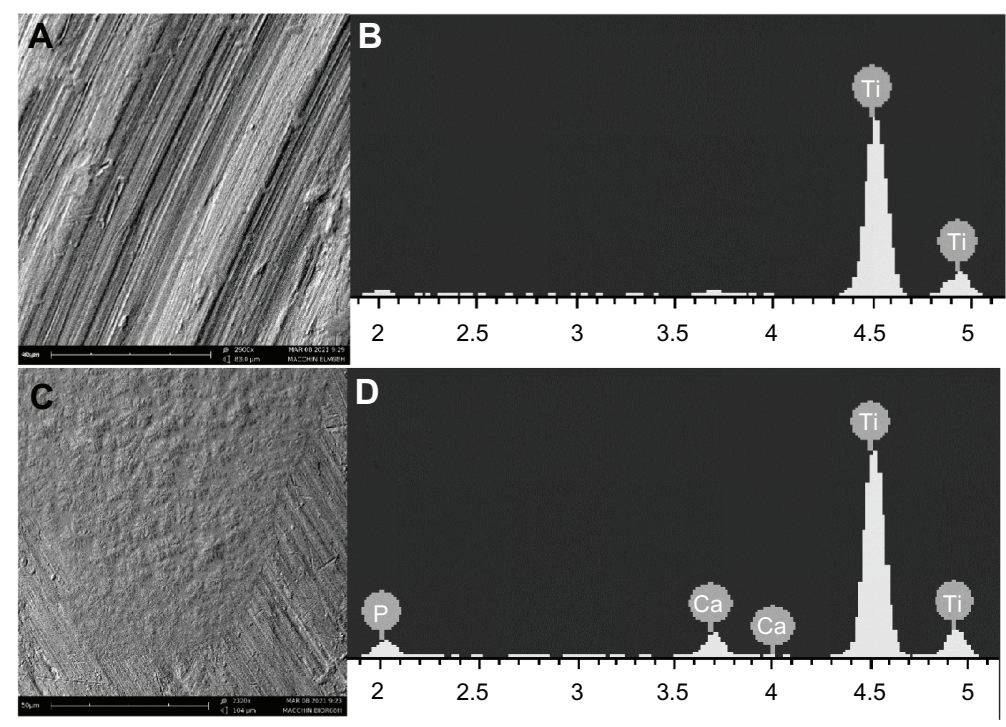

Figure 4 SEM images of titanium surfaces after mouthwash treatments: (A) titanium surface treated $\mathrm{F}^{-}$-based mouthwash, (B) elementary analysis with EDAX probe on titanium surface treated with $\mathrm{F}^{-}$-based mouthwash, (C) titanium surface treated with CHA-based mouthwash; (D) elementary analysis with EDAX probe on titanium surface treated with CHA-based mouthwash.

Abbreviations: CHA, carbonate-hydroxyapatite; EDAX, energy dispersive detector; F-, fluoride; SEM, scanning electron microscopy.

A

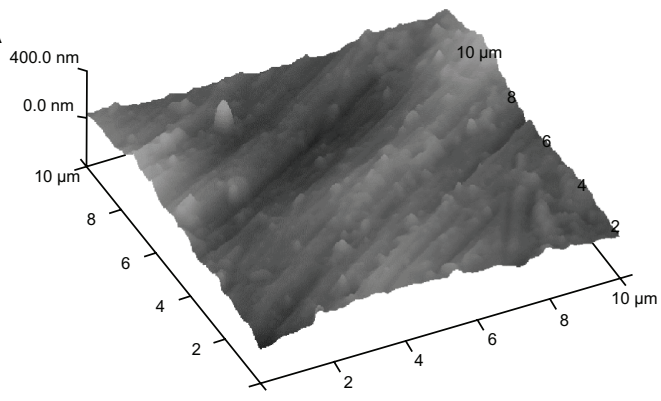

B

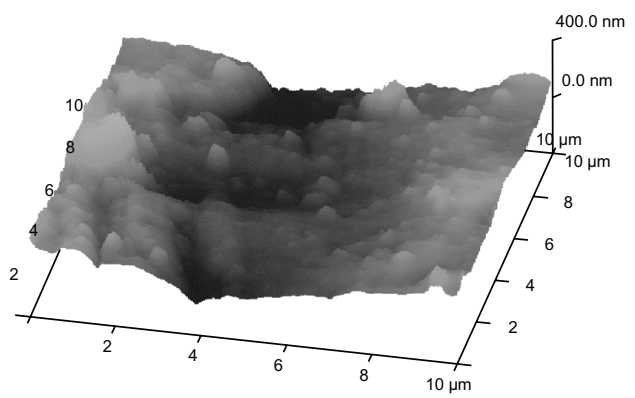

C

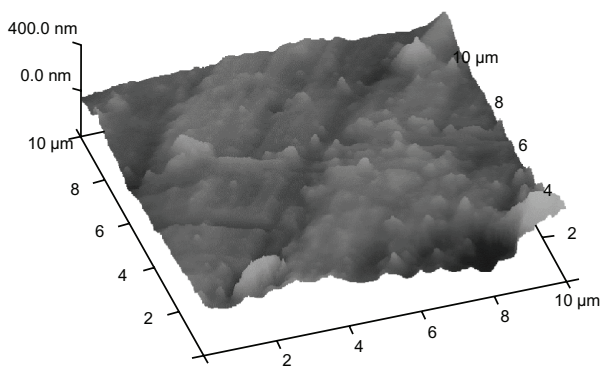

Figure 5 AFM analysis on titanium disks with $10 \times 10 \mu \mathrm{m}$ section: $(\mathbf{A})$ reference titanium plate, (B) titanium plate treated with $\mathrm{F}^{-}$-based mouthwash, (C) titanium plate treated with CHA-based mouthwash.

Abbreviations: AFM, atomic force microscopy; CHA, carbonate-hydroxyapatite; $\mathrm{F}^{-}$, fluoride.

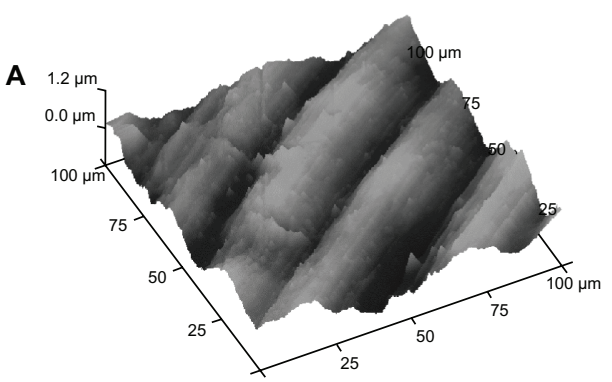

B

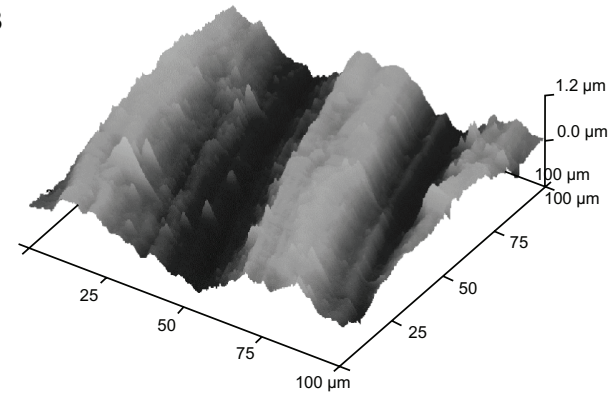

C

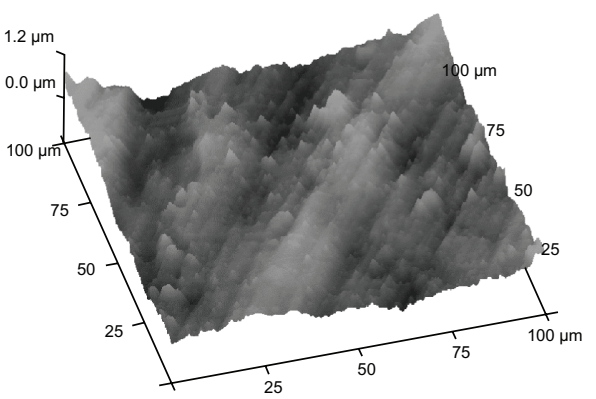

Figure 6 AFM analysis on titanium disks with $100 \times 100 \mu \mathrm{m}$ section: (A) reference titanium plate, $(\mathbf{B})$ titanium plate treated by $\mathrm{F}^{-}$-based mouthwash, $(\mathbf{C})$ titanium plate treated by CHA-based mouthwash.

Abbreviations: AFM, atomic force microscopy; CHA, carbonate-hydroxyapatite; $\mathrm{F}^{-}$, fluoride. 
Titanium plates treated with the two different mouthwashes were investigated using titanium sections of different dimensions. We have examined titanium plate sections of $10 \times 10 \mu \mathrm{m}$ and $100 \times 100 \mu \mathrm{m}$ wide. Figures 5 and 6 show AFM images obtained on the surface of $10 \times 10 \mu \mathrm{m}$ and $100 \times 100 \mu \mathrm{m}$ sections, respectively. In fact, in the $10 \times 10 \mu \mathrm{m}$ samples, AFM measures the surface nanoroughness with high accuracy, while in the $100 \times 100 \mu \mathrm{m}$ samples, it is possible to evaluate the roughness extension with high accuracy.

In Figures $5 \mathrm{~A}$ and $6 \mathrm{~A}$, the $\mathrm{AFM}$ images of the titanium reference surface are reported, in Figures $5 \mathrm{~B}$ and $6 \mathrm{~B}$, the $\mathrm{AFM}$ images of $\mathrm{F}^{-}$mouthwash-treated titanium surface are reported, while in Figures 5C and 6C, the AFM images show the effect of CHA mouthwash on the titanium surface. The numerical analysis carried out on the AFM images is reported in Tables 1 and 2. The root mean square (Rq), highest peak (Rp), and deepest valley (Rv) were measured on $10 \times 10 \mu \mathrm{m}$ sections of reference titanium surface and after treatment with mouthwashes containing $\mathrm{F}^{-}$and CHA (Table 1). The Rq, Rp, and Rv were measured on $100 \times 100 \mu \mathrm{m}$ sections of reference titanium surface and after treatment with the mouthwashes containing $\mathrm{F}^{-}$and CHA (Table 2).

\section{Discussion}

A morphological characterization was performed on the surface of polished, titanium brackets after in vitro treatment with mouthwashes containing amine $\mathrm{F}^{-}$and $\mathrm{CHA}$. Titanium plates treated with the two different mouthwashes were analyzed by SEM and AFM using titanium sections of two different dimensions $(10 \times 10 \mu \mathrm{m}$ and $100 \times 100 \mu \mathrm{m})$ for a well-defined highly accurate evaluation of the modification of surface nanoroughness and its extension (respect the value $\mathrm{Rq}, \mathrm{Rp}$ and $\mathrm{Rv}$ reported in table 2) induced by the treatment with the two different mouthwashes.

Table I AFM analysis of different titanium disks, $10 \times 10 \mu \mathrm{m}$ section

\begin{tabular}{llll}
\hline $\mathbf{1 0} \times 10 \mu \mathrm{m}$ sections & $\begin{array}{l}\text { Root mean } \\
\text { square (Rq) }\end{array}$ & $\begin{array}{l}\text { Highest } \\
\text { peak (Rp) }\end{array}$ & $\begin{array}{l}\text { Deepest } \\
\text { valley (Rv) }\end{array}$ \\
\hline $\begin{array}{l}\text { Polished titanium disk } \\
\text { (reference) }\end{array}$ & $93 \mathrm{~nm}$ & $350 \mathrm{~nm}$ & $-140 \mathrm{~nm}$ \\
$\begin{array}{l}\text { F--based mouthwash } \\
\text { treated disk }\end{array}$ & $92 \mathrm{~nm}$ & $460 \mathrm{~nm}$ & $-230 \mathrm{~nm}$ \\
$\begin{array}{l}\text { CHA-based mouthwash } \\
\text { treated disk }\end{array}$ & $56 \mathrm{~nm}$ & $300 \mathrm{~nm}$ & $-120 \mathrm{~nm}$ \\
\hline
\end{tabular}

Abbreviations: AFM, atomic force microscopy; CHA, carbonate-hydroxyapatite; $\mathrm{F}^{-}$, fluoride.
Table 2 AFM analysis of different titanium disks, $100 \times 100 \mu \mathrm{m}$ section

\begin{tabular}{llll}
\hline $100 \times 100 \mu \mathrm{m}$ & $\begin{array}{l}\text { Root mean } \\
\text { square (Rq) }\end{array}$ & $\begin{array}{l}\text { Highest } \\
\text { peak (Rp) }\end{array}$ & $\begin{array}{l}\text { Deepest } \\
\text { valley (Rv) }\end{array}$ \\
\hline $\begin{array}{l}\text { Polished titanium disk } \\
\text { (reference) }\end{array}$ & $280 \mathrm{~nm}$ & $700 \mathrm{~nm}$ & $-740 \mathrm{~nm}$ \\
$\begin{array}{l}\text { F--based mouthwash } \\
\text { treated disk }\end{array}$ & $460 \mathrm{~nm}$ & $840 \mathrm{~nm}$ & $-940 \mathrm{~nm}$ \\
$\begin{array}{l}\text { CHA-based mouthwash } \\
\text { treated disk }\end{array}$ & $235 \mathrm{~nm}$ & $620 \mathrm{~nm}$ & $-520 \mathrm{~nm}$ \\
\hline
\end{tabular}

Abbreviations: AFM, atomic force microscopy; CHA, carbonate-hydroxyapatite; F-, fluoride.

The treatment with the $\mathrm{F}^{-}$-based mouthwash induces a roughness characterized by streaking with higher peaks and deeper valleys on the titanium bracket surface compared with those observed in the reference polished titanium plates. Contrarily, the treatment with the CHA-based mouthwash induces a roughness characterized by streaking with smoothed peaks and less deep valleys on the titanium bracket surface compared with those observed in the reference polished titanium disc. These findings can be explained by the hydroxyapatite deposition filling the streaks on the titanium surface and therefore reducing surface roughness. The EDAX analysis revealed the presence of calcium and phosphorus in a molar ratio of 1.7 , which was characteristic of the CHA present in the mouthwash.

The increased roughness induced by the in vitro treatment with the mouthwash containing amine $\mathrm{F}^{-}$ (Tables 1 and 2) modify the mechanical behavior of the titanium brackets, which promotes a mechanical weakness of the metallic dental implant. The increased depth of the streaks encourage bacterial growth promoting infection and prosthesis contamination and mobility. ${ }^{44}$ Contrarily, the in vitro treatment with the CHA-based mouthwash reduces the surface roughness by filling in the streaks (Tables 1 and 2). This hydroxyapatite deposition protects against the surface oxidative process, which can damage the mechanical behavior of the titanium brackets. The depositation of hydroxyapatite coating on titanium surface is able to prevent the bacterial growth contaminating the prosthesis. Furthermore, when bacterial plaque, by its acidity, solubilizes the zinc-substituted CHA present on the titanium implant. ${ }^{40,41,45}$ On one hand, our data shows that the presence of $\mathrm{F}^{-}$in mouthwashes should be avoided to prevent any degradation of the metallic dental implant and subsequent contamination with bacteria. On the other hand, the CHA-based mouthwash prevents the degradation of the metallic dental implants and the formation of bacterial film. 


\section{Conclusion}

The morphological characterization of the surface of polished titanium brackets after in vitro treatments with a mouthwash containing an amine $\mathrm{F}^{-}$and another containing CHA showed that the presence of $\mathrm{F}^{-}$in a mouthwash induces mechanical weakness in the metallic dental implant and bacterial contamination. The presence of zinc-substituted CHA in a mouthwash prevents the deterioration of the metallic dental implant and contamination with bacteria.

\section{Acknowledgment}

We thank the RBAP114AMK, RINAME Project, "Rete integrata per la nano medicina" (funds for selected research topics), the Chemical Center Srl, and the Interuniversity Consortium for Research on Chemistry of Metals in Biological Systems (CIRCMSB) for the financial support.

\section{Disclosure}

The authors report no conflicts of interest in this work and no payment has been received for the preparation of this manuscript.

\section{References}

1. Ellingsen JE. Pre-treatment of titanium implants with fluoride improves their retention in bone. J Mater Sci Mater Med. 1995;6:749-753.

2. Correa CB, Pires JR, Fernandes-Filho RB, Sartori R, Vaz LG. Fatigue and fluoride corrosion on Streptococcus mutans adherence to titaniumbased implant/component surfaces. J Prosthodont. 2009;18:382-387.

3. Lelli M, Montebugnoli G, Roveri N. Biomimetic nanostructured hydroxyapatite functionalized for biomedical applications. 2012;44;7;101-127.

4. Orsini G, Procaccini M, Manzoli M, Giuliodori F, Lorenzini A, Putignanol A. A double-blind randomized-controlled trial comparing the desensitizing efficacy of a new dentifrice containing carbonate/ hydroxyapatite nanocrystals and a sodium fluoride/potassium nitrate dentifrice. J Clin Periodontol. 2010;37:510-517.

5. Garcia-Godoy F, Hicks MJ. Maintaining the integrity of the enamel surface: the role of dental biofilm, saliva and preventive agent in enamel demineralization and remineralization. J Am Dent Assoc. 2008; 139(Suppl):25S-34S.

6. Fowler CE, Garcia L, Edwards MI, Wilson R, Brown A, Rees GD. Inhibition of enamel erosion and promotion of lesion rehardening by fluoride: a white light interferometry and microidentation study. J Clin Dent. 2009;20(6):178-185.

7. Joshua J, Jacobs MD, Jeremy L, Gilbert D, Robert M. Corrosion of metal orthopaedic implants. J Bone Joint Surg Am. 1998;80(2):268-282.

8. Blackwood DJ, Chooi SKM. Stability of protective oxide films formed on a porous titanium. Corros Sci. 2002;44(3):395-405.

9. Mabilleau G, Bourdon S, Joly-Guillou ML, Filmon R, Baslé MF, Chappard D. Influence of fluoride, hydrogen peroxide and lactic acid on the corrosion resistance of commercially pure titanium. Acta Biomater. 2006;2(1):121-129.

10. Stàjer $\mathrm{A}$, Ungvàri $\mathrm{K}$, Pelsòczi $\mathrm{IK}$, et al. Corrosive effect of fluoride in titanium: Investigation by X-ray photoelectron spectroscopy, atomic force microscopy, and human epithelial cell culturing. J Biomed Mater Res. 2008;87A:450-458.

11. Coleman HM, Marquis CP, Scott JA, Chin S-S, Amal R. Bactericidal effects of titanium dioxide-based photocatalysts. Chem Eng J. 2005; 113(1):55-63.
12. Norimoto MMK, Kimura T. Antibacterial activity of photocatalytic titanium dioxide thin films with photodeposited silver on the surface of sanitary ware. J Am Ceram Soc. 2005;88(1):95-100.

13. Harzer W, Schroter A, Gedrange T, Muschter F. Sensitivity of titanium brackets to the corrosive influence of fluoride-containing toothpaste and tea. Angle Orthod. 2001;71(4):314-323.

14. Salerno M, Giacomelli L, Derchi G, Patra N, Diaspro A. Atomic force microscopy in vitro study of surface roughness and fractal character of a dental restoration composite after air-polishing. Biomed Eng Online. 2010;9:59-62.

15. Erlard S, Buchanan SN. A quantitative look at fluorosis, fluoride exposure, and intake in children using a health risk assessment approach. Environ Health Perspect. 2005;113(1):111-117.

16. Roveri N, Foresti E, Lelli M, Lesci IG. Recent advancements in preventing teeth health hazard: the daily use of hydroxyapatite instead of fluoride. Recent Pat Biomed Eng. 2009;2(3):197-215.

17. Roveri N, Palazzo B. Tissue, Cell and Organ Engineering. Weinheim, Germany: Wiley-VCH; 2006.

18. Brunelle JA, Carlos JP. Recent trends in dental caries in US children and the effect of water fluoridation. J Dent Res. 1990;69:723-727.

19. Arnold FA Jr, Trendley Dean H, Jay P, Knutson JW. Effect of fluoridated public water supplies on dental caries prevalence. Public Health Rep. 1956;71(7):652-658.

20. Johnson WJ, Taves DR, Jowsey J. Fluoridation and bone disease in renal patients. In: Johansen E, Taves DR, Olsen TO, editors. Evaluation of the Use of Fluorides. American Association for the Advancement of Science; 1979. Available at http://www.fluoridealert.org/studies/mayoclinic/.

21. Boivin G, Chavassieux P, Chapuy C, Baud CA, Meunier PJ. Skeletal fluorosis: Histomorphometric analysis of bone changes and bone fluoride content in 29 patients. Bone. 1989;10(2):89-99.

22. Aasenden R, Peebles TC. Effects of fluoride supplementation from birth on dental caries and fluorosis in teenaged children. Arch Oral Biol. 1978;23(2):111-115.

23. Rozier RG. The prevalence and severity of enamel fluorosis in North American children. J Public Health Dent. 1999;59(4):239-246.

24. Bow JS, Liou SC, Chen SY. Structural characterization of roomtemperature synthesized nano-sized beta-tricalcium phosphate. Biomaterials. 2004;25:3155-3161.

25. Hench LL, Kokubo T. In: Black J, Hastings G, editors. Handbook of Biomaterials Properties. London, UK: Chapman and Hall; 1998: 355-364.

26. Roveri N, Foresti E, Lelli M, Lesci IG, Marchetti M. Microscopic investigations of synthetic biomimetic hydroxyapatite. In: Méndez-Vilas A, Díaz J, editors. Microscopy: Science, Technology, Applications and Education. FORMATEX ED. Spain. 2010:1868-1876.

27. Driessens F. Formation and stability of calcium phosphates in relation to the phase composition of the mineral in calcified tissues. In: Ed. DeGroot, K. CRC Press, Boca Raton, FL; 1983

28. Rey C, Renugopalakrishnan V, Collins B, Glimcher MJ. Fourier transform infrared spectroscopic study of the carbonate ions in bone mineral during aging. Calcif Tissue Int. 1991;49(4):251-258.

29. Burnell JM, Teubner EJ, Miller AG. Normal maturational changes in bone matrix, mineral, and crystal size in the rat. Calcif Tissue Int. 1980;31(1):13-19.

30. Roveri N, Palazzo B, Iafisco M. The role of biomimetism in developing nanostructured inorganic matrices for drug delivery. Exp Opin Drug Deliv. 2008;5(8):861-877.

31. Palazzo B, Iafisco M, Laforgia M, et al. Biomimetic hydroxyapatite-drug nanocrystals as potential bone substitutes with antitumor drug delivery. Adv Funct Mat. 2007;17(13):2180-2188.

32. Iafisco M, Palazzo B, Marchetti M, et al. Smart delivery of antitumoral platinum complexes from biomimetic hydroxyapatite nanocrystals. J Mater Chem. 2009;19:8385-8392.

33. Iafisco M, Palazzo B, Martra G, et al. Nanocrystalline carbonateapatites: role of $\mathrm{Ca} / \mathrm{P}$ ratio on the upload and release of anticancer platinum bisphosphonates. Nanoscale. 2012;4(1):206-217. 
34. Palazzo B, Walsh D, Iafisco M, et al. Amino acid synergetic effect on structure, morphology and surface properties of biomimetic apatite nanocrystals. Acta Biomater. 2009;5(4):1241-1252.

35. Iafisco M, Palazzo B, Falini G, et al. Adsorption and conformational change of myoglobin on biomimetic hydroxyapatite nanocrystals functionalized with alendronate. Langmuir. 2008;24(9):4924-4930.

36. Iafisco M, Di Foggia M, Bonora S, Pratt M, Roveri N. Adsorption and spectroscopic characterization of lactoferrin on hydroxyapatite nanocrystals. Dalton Trans. 2011;40(4):820-827.

37. Palazzo B, Roveri N, Iafisco M, Rimondini L, Gazzaniga G, Gualandi P. 2006:EP005146. Biologically active nanoparticles of a carbonate substituted hydroxyapatite process for their preparation and composition incorporating the same.

38. Roveri N, Battistella E, Foltran I, et al. Synthetic biomimetic carbonatehydroxyapatite nanocrystals for enamel remineralisation. Adv Mater Res. 2008;47-50:821-824.

39. Lorenzini A, Orsini G, Lelli M, et al. Remineralization/repair of enamel surface by biomimetic Zn-carbonate hydroxyapatite containing dentifrice. J Dent Res. 2011;89(Special Issue A):147955. Available at http://iadr.confex.com/iadr/2011 sandiego/webprogram/Paper147955. html.
40. Rimondini L, Palazzo B, Iafisco M, et al. The remineralizing effect of carbonate-hydroxyapatite nanocrystals on dentine. Materials Science Forum. 2007;539-543:602-605.

41. Roveri N, Battistella E, Bianchi I, et al. Surface enamel remineralization: biomimetic apatite nanocrystals and fluoride ions different effects. J Nanomater. 2009;1:1-9. Available at http://www.hindawi.com/ journals/jnm/2009/746383/.

42. Manara S, Paolucci F, Palazzo B, et al. Electrochemically assisted deposition of biomimetic hydroxyapatite-collagen coatings on titanium plate. Inorg Chim Acta. 2008;361(6):1634-1645.

43. Lelli M, Foltran I, Foresti E, et al. Biomorphic silicon carbide coated with an electrodeposition of nanostructured hydroxyapatite/collagen as biomimetic bone filler and scaffold. Adv Eng Mater. 2010;12(8): B348-B355.

44. Drake DR, Paul J, Keller JC. Primary bacterial colonization of implant surface. Int J Oral Maxillofac Implants. 1999;14:226-232.

45. Lelli M, Roveri N. Electrodeposited Biomimetic Hydroxyapatite for Osteo-Integration and Drug Delivery. Electrodeposition: Properties, Processes and Applications. Nova Science Publishers, Editor: Udit surya mohanty, pp. Inc; 2011;10:1-13.
International Journal of Nanomedicine

\section{Publish your work in this journal}

The International Journal of Nanomedicine is an international, peerreviewed journal focusing on the application of nanotechnology in diagnostics, therapeutics, and drug delivery systems throughout the biomedical field. This journal is indexed on PubMed Central, MedLine, CAS, SciSearch $\AA$, Current Contents ${ }^{\circledR} /$ Clinical Medicine,

\section{Dovepress}

Journal Citation Reports/Science Edition, EMBase, Scopus and the Elsevier Bibliographic databases. The manuscript management system is completely online and includes a very quick and fair peer-review system, which is all easy to use. Visit http://www.dovepress.com/ testimonials.php to read real quotes from published authors. 